\title{
O Senado na Constituição de 1934
}

(Discursos pronunciados no Senado Federal

a 27 e 28 de Agosto de 1936).

Alcantara Machado

I

\section{A ATMOSFERA DA CONSTITUINTE}

Em trabalho de publicação recente um observador de nossa vida política acentua que a revisão profunda da obra constitucional de 1891 nunca foi reclamada por correntes consideraveis da opinião. Havia naturalmente quem a advogasse. Mas o sentir comum era diferente. Quasi todos davam razão a Pedro Lessa, quando averbava de pueril a tendencia tão espalhada entre as nações atrazadas e debeis de apelar a cada instante para aquele expediente como remedio aos males que as afligem.

Se me julgasse obrigado a demonstrar verdade histórica de tamanha evidencia, eu lembraria que a iniciativa de Rui em 1910 não teve ressonancia duradoura na conciencia nacional; que os movimentos armados de 22 e 24 se propunham pura e simplesmente á destituição violenta dos detentores do poder; que, embora parcial, a reforma de 26 des- 
pertou protestos veementes; que tanto a Reacção Republicana como a Aliança Liberal propugnavam, não a substituição, mas a prática honesta do regime; que a propria revolução de 30 não desfraldou jamais durante a luta a bandeira da revisão integral.

Só depois da vitoria foi que alguns de seus autores tornaram público o pensamento, que lhes sobreviera, de remodelar a estrutura política do paiz; e trataram de arranjar ás pressas aquela ideclogia de emergencia, de que falou certa vez o ilustre sr. Odilon Braga. Uma revolução á procura de un programa, tal o espetáculo que durante longo tempo se desenrolou aos nossos olhos.

Em um ponto se mostravam acordes os senhores e possuidores do espírito revolucionario: era preciso conformar a Constituição com a realidade brasileira. As divergencias começavam, inumeraveis e irredutiveis, quando procuravam explicar o sentido da expressão. Verificou-se que estávamos diante de uma dessas fórmulas elásticas e cômodas, em que cada qual tem o direito de pôr o que bem lhe pareça.

Tanto assim que vimos preconisadas, em nome da famosa realidade, as idéas mais estranhas ao ambiente nacional: o fascismo italiano, o Estado Novo português, a ditadura comtista, o comunismo russo, a democracia espanhola, a social democracia alemã. Invocavam-na simultaneamente unitaristas, federalistas, confederacionistas. Era em sua defesa que se levantavam os presidencialistas intransigentes, os parlamentaristas convictos, os ditatoriaes confessos.

Foi nessa atmusfera de confusão e balbúrdia que se organizou o ante-projeto do Itamaratí, ao calor de talentos peregrinos, como os dos srs. Osvaldo Aranha, Afrânio de Melo Franco e João Mangabeira; e que se iniciaram os trabalhos da Constituinte sob o olhar rutilante de inteligencia e de malícia do eminente sr. Antonio Carlos.

Ninguem melhor do que v. exa., que foi um dos grandes condutores da Assembléa, póde dar testemunho da des- 
orientação reinante naqueles dias incertos e amargos; e das apreensões que despertava nos espíritos conservadores, educados no respeito de nossa ordem social e de nossas tradições jurídicas, a desenvoltura com que se pregavam abertamente as doutrinas mais subversivas e perigosas. A' apologia do Estado totalitario sucedia o incitamento á luta das classes. A' condenação da democracia, o elogio hiperbólico da organização marxista.

O que mais contribuia para aumentar o alarme em que viviamos era a simpatia calorosa que alguns dentre os agentes mais graduados e prestigiosos do poder dispensavam a essas idéas dissolventes e malsãs. Dois episodios de que fomos testemunhas, v. exa. e eu, bastam para demonstrar a anarquia mental de um tempo que nos parece tão remoto e de que todavia só nos separam dois anos. Nas reuniões matinaes em que se congregavam os líderes para assentar as votações do plenario ouvimos estarrecidos um dos ministros do governo provisorio confessar que, em nome deste último, se havia comprometido a dar á representação classista a metade da Câmara, ferindo assim de morte o regime democrático; e outro pleitear a tese sabidamente extremista da unidade sindical, tese que só não foi vitoriosa na constituição de $\mathbf{1 6}$ de julho, devido á resistencia da bancada paulista da Chapa Unica, da bancada paraibana, da bancada católica do Ceará, da bancada mineira e de algumas outras, de que não guardo memoria.

Não é de espantar que, trabalhada por idéas e paixões. antagônicas, ameaçada abertamente de dissolução por um. golpe militar, urgida pela opinião que anceava pelo retorno imediato ao regime da lei, a constituinte haja realizado uma obra muito distante da perfeição. Assombro é que, em circunstancias tão desfavoraveis, tenha conseguido levá-la a termo; e que não sejam mais numerosas e mais graves as imperfeições que apresenta, de ordem técnica e de ordem política. 
A maioria dessas imperfeições veiu da necessidade, em que se viram os elementos moderados, de transigir em certos pontos, para evitar maiores maleficios. Púnhamos a nossa confiança no tempo. O tempo demonstraria, como demonstrou, com a tristíssima lição de novembro, que a razão estava com os espíritos conservadores, e não com os que pretendiam impelir-nos violentamente para a estrema direita ou para a estrema esquerda. Agora que o instinto de conservação dos responsaveis pelos destinos do paiz situa no centro o eixo da política nacional, parece chegado o ensejo de irmos examinando, á luz da experiencia deste biênio, os defeitos mais sensiveis da constituição vigente, para que tratemos oportunamente de remedia-los.

Entre esses defeitos nenhum sobreleva, a meu ver, em peso e volume, ao que resulta da organização do poder legislativo.

\section{OS DOIS SISTEMAS: NA TEORIA E NA PRATICA}

Um dos raríssimos pontos em que se mostravam de acôrdo os donos do momento, era a condenação do Senado. Dir-se-ia que êle encarnava, aos olhos dos vencedores, todcs os vicios, mazelas e impurezas do nosso organismo político. Bastava pronunciar-lhe o nome para desencadear a tempestade. Tanto assim que a aprovação da emenda paulista de redação, que restabeleceu a denominaçãc tradicional desta casa, foi recebida por certos elementos vermelhos da constituinte com brados de indignação e revolta. Houve mesmo quem gritasse que estavamos destruindo a obra da revolução vitoriosa, com a simples substituição do rótulo de "Conselho Federal" pelo de "Senado"

Porque tamanha ogerisa contra a instituição?

O que, em suma, lhe imputavam os seus inimigos eram a subalternidade ao chefe do executivo e cs atentados contra a verdade eleitoral na verificação de poderes. Não se 
tratava, porém, de pecados específicos ou privativos do antigo Senado. Os reconhecimentos escandalosos em conflito com o resultado das apurações e a atitude servil deante dos mandamentos do Catete, abundavam igualmente nos dois ramos do poder legislativo. Não preciso citar exemplos, tão vivos se encontram êles na memoria dos contemporaneos. Nem por isso, entretanto, se pensava em suprimir a Câmara dos Deputados, né de culpas idênticas e passivel em boa justiça da mesma pena. O que a razão indicava não era a eliminação do órgão, e sim a remoção das causas de seu funcionamento defeituoso. Já o fizera o Código Eleitoral. A nova constituição viria completar a obra de saneamento. O remedio consistia, com ef eito, em confiar á justiça o processo das eleições, dando ao eleitorado a certeza de que o seu voto seria respeitado e aos eleitos a conciencia de que representavam de fato a vontade do povo.

Nem assim os adversarios do Senado se mostravam convencidos. Restava-lhes como recurso o apêlo aos velhos argumentos de ordem teórica e de ordem prática, que desde muito se vem repetindo contra a bi-cameralidade.

Reeditou-se a objeção de Raband-Saint'Etienne: o poder legislativo deve ser uno e simples como una e simples é a soberania nacional. A refutação está nos livros clássicos de Duguit e Barthelemy-Duez. A dualidade das câmaras não importa, com efeito, no parcelamento da soberania: o poder legislativo continua a ser uno na sua essencia, embora complexo em sua estrutura. Ademais, levado as ultimas consequencias, o argumento obrigaria á extinção dos outros órgãos do Estado e até a redução da câmara única a uma única pessoa.

Voltou á balha o dilema de Bentham: ou a segunda câmara concordará com a outra e será supérflua, ou dela divergirá e se tornará odiosa. O dilema nos conduziria logicamente ás maiores enormidades: a suprimir os recursos em materia administrativa e em materia judicial, e a sanção e o veto em materia legislativa. Acresce que a discordancia nada tem de odiosa, porque importa apenas em 
provocar novo exame da questão pela câmara iniciadora, e nada tem de supérflua a concordancia, que contribue para prestigiar a lei como expressão da vontade geral.

Retornaram á circulação outras alegações, igualmente sediças e igualmente frageis.

Assim, a possibilidade de conflitos entre os dois ramos do parlamento, conflitos que, conforme demonstra a experiencia e Duguit assinala, nunca levam á anarquia, terminando invariavelmente por concessões recíprocas, o que é proprio dos governos moderados.

Assim o enfraquecimento do legislativo diante do executivo, enfraquecimento que a unicameralidade não conseguiu jamais evitar e que é fruto, não das instituições, mas dos imperativos ditados pela segurança nacional, nas horas de perigo, ou em tempos normaes, pela pusilanimidade dos representantes do povo.

Assim, o retardamento da elaboração legislativa, retardamento que em regra é proveitoso, porque permite a meditação e a prudencia na adoção de reformas políticas e sociaes; e que não se verifica nos casos de urgencia, quando se trata de medidas reclamadas pela salvação pública ou impostas categoricamente pela opinião. Quem ha que se não lembre de como foi votada pelas duas casas do parlamento do Imperio a lei de $\mathbf{1 3}$ de Maio? E não é de ôntem a votação rápida, aqui e na Câmara, das emendas constitucionaes?

Concedamos, "gratia argumentandi", que procedessem todas essas objeções. O que manda a sabedoria política não é procurar a fórmula impecavel e perfeita, que não existe; mas dentre as várias soluções escolher a que apresenta maiores vantagens e menores inconvenientes of erece. Ora, os argumentos que militam em favor da dualidade das camaras são quantitativa e qualitativamente superiores aos que se apontam em favor da unidade.

Ha a considerar, antes de tudo, o perigo que para a comunhão representa a existencia de uma câmara única. A observação atesta e os mestres proclamam que toda as- 
sembléa tende fatalmente a tornar-se precipitada, corrompida e tirânica. O seu despotismo não é menos temivel, nem menos funesto do que o das monarquias absolutas ou ditaduras. O meio de conjurar semelhante ameaça é dividir o poder legislativo em duas câmaras, de autoridade equivalente. Se perder com a unidade o excesso de força, voltará êle a ser o que deve ser, em verdade, isto é, igual aos outros poderes. E' a lição de Story, de Hamilton, de Bryce, de Laboulaye, de Duguit, de Barthelemy-Duez, de Moreau, de Esmein, de Marnoco e Sousa, de Carlos Maximiliano.

Não é só. Por sua propria organização, pela maior duração de seu mandato, pela autoridade que lhe conferem a madureza e a experiencia de seus membros, o Senado está naturalmente indicado para servir de medianeiro ou mediador plástico nos conflitos possiveis entre a câmara popular e o governo. E' êle que, em taes casos, encontra a fórmula de conciliação e impede que, com o sacrificio das instituições, a luta se transforme em duelo de vida e de morte.

Ainda mais. A dualidade contribue eficaz e decisivamente para o aperfeiçoamento da obra legislativa. As decisões de uma unica assembléa, por mais incorretas e defeituosas que sejam, tornam-se desde logo definitivas e praticamente irreparaveis, porque o decoro da corporação não lhe permitiria corrigir desde logo os erros praticados. Tudo isso poderá ser evitado com a sujeição do projeto a novo exame e nova deliberação de outra Câmara.

Acresce que a dualidade tem por fundamento a propria natureza humana. De fato, coexistem na alma individual e na alma coletiva duas tendencias contraditorias, que, compensadas, asseguram o desenvolvimento harmonioso do indivíduo e da coletividade: a tentação de mudar, reformar, inovar, e o receio de modificar o que existe; a ânsia do progresso e o respeito da tradição. Pois bem: a bi-cameralidade corresponde á necessidade da concorrencia e da composição dessas duas forças, igualmente uteis, na definição do direito positivo. Para me servir das palavras 
de Pomeroy, citadas por Carlos Maximiliano, a Câmara é a onda que impele, o Senado a âncora que segura. A primeira imprime rapidez, o segundo garante a estabilidade. Aquela desempenha a função de elemento progressivo, este a de elemento conservador. Uma reflete a vontade movediça da multidão, e o outro os sentimentos profundos da nacionalidade.

Lembrarei, por último, aquele argumento extraido da experiencia multi-secular do homem, de que fala o sr. Odilon Braga no estudo magistral que me vem servindo de roteiro. Argumento decisivo, porque, no dizer de Faguet, são os fatos e não as teorias que governam a humanidade.

A historia dá razão a Bluntschli, quando o insigne professor de Heidelberg afirma que nenhuma das grandes nações ocidentaes adotou a unicameralidade, senão transitoriamente, depois de convulsões profundas, como instrumento de opressão do partido triunfante sobre as facções contrarias. Assim, na Inglaterra, depois da execução de Carlos I; na França em 1791 e 1848; na Espanha em 1910 e 1930; na Alemanha em 1848 e 1918.

Mostra-nos ainda que só os paizes pequeninos ou atrazados, em que não são marcados os antagonismos sociaes, conseguem suportar o sistema unicameral. Fóra daí, tem êle produzido sempre e em toda parte os resultados mais perniciosos. Foi o que se deu na França, depois das revoluções de 89 e 48 . Foi o que aconteceu na Argentina que, consoante o depoimento de Alberdi, se tornou desgraçada, todas as quatro vezes que concentrou numa só assembléa o poder legislativo. Foi o que se verificou na Alemanha, durante a vigencia da constituição de Weimar, cujo fracasso é imputado pelos sabedores ao repúdio da bi-cameralidade. E' o que ainda agora se está presenciando na Espanha, que não quiz atender ás sábias advertencias de Alcalá Zamora. Assim, efêmera e tormentosa se mostra em toda a parte a vida dos regimes, que com a abolição da segunda câmara, perdem um órgão essencial de ponderação e de equilibrio. Que contraste oferecem, no que respeita á es- 
tabilidade, as nações em que vigora o sistema oposto! São absolutamente demonstrativos os exemplos que nesse particular nos fornecem a Grã Bretanha, os Estados Unidos, a Suissa, a Bélgica, a Holanda, os paises escandinavos. Mais eloquente, ainda, é o ensinamento da França, que só conheceu uma relativa tranquilidade política, depois que se decidiu em 1875 pela instituição do Senado. O papel eminente, que o Senado francez vem desde então desempenhando na consolidação da terceira República, disse-o Alcalá Zamora na constituinte espanhola: deante de governos apaixonados ou frouxos, em face de câmaras reacionarias ou demagógicas, êle se mantem sempre á altura da sua missão, resistindo igualmente ás demasias da esquerda e aos excessos da direita, malogrando os golpes do Estado, adiando as reformas prematuras, conservando-se equidistante dos retardatarios e dos precipitados.

Tudo isso tem levado a quasi unanimidade dos paizes, em que vigora o sistema representativo, á adoção da bicameralidade. Essa universalidade está a denunciar que a dualidade do corpo legislativo corresponde a uma necessidade orgânica, no dizer de Carlos Maximiliano, e autozanos a afirmar como Odilon Braga a naturalidade irresistivel da medida.

\section{III}

\section{BI-CAMERALISMO E FEDERALISMO}

Mas, além de ser providencia reclamada pela razão e aconselhada pela experiencia, o desdobramento do órgão deliberante constitue nos estados federaes, como o Brasil, um dos consectarios lógicos do regime.

Fatigante e excusađa seria a exposição das velhas e novas teorias sobre a natureza juridica da federação. Bastar-me-á recordar que, de acôrdo com a opinião corrente, é condição existencial daquela entidade a participação dos Estados particulares na criação da vontade soḅerana da União. Dizem-no em sua infinita maioria as autoridades no. 
materia, desde Le Fur, Laband, Borel, até os autores mais recentes como Kunz e Mouskheli. Tem aparecido um ou outro díscolo. Durand, por exemplo. Mouskheli, deu-lhe, porém, resposta imediata e concludente, demonstrando que em todas as federações e só nas federações se nos depara, privativo e constante, o elemento precitado, o que obriga á conclusão de que se trata de um sinal específico do estado federal.

Sempre se entendeu que semelhante participação deve ser completa, isto é, que deve estender-se a toda a legislação nacional. Daí, a necessidade da existencia de duas câmaras, investidas das mesmas faculdades legislativas. Uma, destinada a representar os Estados particulares, como taes, isto é, como unidades políticas; outra, destinada a representar o povo em conjunto. Esta, proporcional á população: os Estados se consideram para esse efeito simples distritos eleitoraes. Aquela com representação, que, em tese, deve ser numericamente igual, de todos os Estados, por isso que juridicamente iguaes são todos êles, sejam quaes forem a sua extensão territorial ou a sua importancia demográfica; mas que, por motivos de ordem histórica ou política, pode não ser paritária, como hoje em dia sucede no Canadá e sucedia outróra no Imperio Alemão, onde, no dizer de Le Fur, seria impossivel a cidade livre de Lubeck e o principado de Lippe terem representação idêntica á da Baviera ou da Prussia. A paridade é imposição lógica; mas a disparidade não revoga o principio, visto que fica sempre assegurada a colaboração de todos os Estados na atividade legislativa da União.

E' o que Carré de Malberg justifica luminosanente: a dualidade das câmaras assim organizadas resulta do proprio dualismo do Estado federal, em que se realizam a união de uma coletividade de cidadãos e a união de uma coletividade de Estados; de modo que, uma câmara só, eleita pelos cidadãos ou eleita pelos Estados, só teria a qualidade para atuar em nome destes ou daqueles, e nunca em nome de uns e de outros. 
E' o que se observa nos Estados Unidos e na Suissa e de Estado, conforme reconhecem os proprios autores que, como Harold Laski e João Barbalho, são contrarios em tese á bi-cameralidade.

E' o que resulta necessariamente dessa forma especial nos paizes que lhes tomaram por modelo as instituições: no Brasil de 91, na Argentina, no Mexico, na Venezuela, na Africa do Sul, na Australia.

Em todos êles encontramos a bi-partição do corpo legislativo. Em todos êles a câmara que representa os Estados membros têm as mesmas faculdades legislativas, sendo indispensavel a colaboração de ambas para a perfeição da lei. Durand e Mouskheli contestam que a participação assim configurada seja condição essencial do regime federativo. Porque? Porque existe um Estado federal, que é a Australia, em que esta condição não se verifica. Nada menos verdadeiro. A constituição australiana não se afasta neste particular das outras constituições federaes: nenhum projeto se converte em lei sem a aprovação das duas câsas do legislativo. Onde foram descobrir aqueles dois escritores a excepção que alegam? Citam êles o dispositivo que, no caso de divergencia entre os dois ramos do parlamento, autoriza o governador a dissolvê-los, e manda que, na hipótese do novo Senado e da nova Câmara continuarem divergentes, seja o confito resolvido em sessão plenaria por maioria de votos; o que ao ver dos autores em questão, reduz a quasi nada a autoridade do Senado, por isso que, menos numeroso do que a Câmara, será vencido inevitavelmente por esta última.

O argumento é de fragilidade manifesta. Salta aos olhos, antes de tudo, que participação não significa preponderancia ou prevalencia, nem etimológica, nem juridicamente; e sim o fato de tomar parte ou cooperar ou colaborar em alguma coisa; e, pois, não ha negar que o Senado australiano participa da deliberação tomada em sessão conjunta pelo parlamento, em que se integra. A prevalecer o argumento chegariamos ao absurdo de negar a participa- 
ção das minorias na atividade das assembléas em que existam. Acresce que no sistema australiano a anulação da vontade do Senado pela vontade da Câmara é hipótese praticamente irrealizavel. De fato, ocorrido o desacôrdo sobre determinado projeto entre as duas casas de parlamento, ambas são dissolvidas. Que significa isso? Que o povo é chamado a pronunciar-se por uma das teses em conflito. Assim, a Câmara e o Senado que forem eleitos refletirão forçosamente o mesmo pensamento com referencia ao projeto, e resolverão o caso concordemente.

Daí se vê que a regra não tem, nem comporta exceções; e que desaparece o único argumento, em que se baseiam os seus contraditores.

Assinale-se de passagem a contradição palpavel, em que neste passo incorre Mouskheli. Ele é o primeiro a acentuar que a participação estadual na formação da vontade da União constitue o sinal específico do regime federativo; que mais conforme com a natureza deste ultimo é a igualdade das faculdades legislativas da câmara dos Estados ou senado federal e da câmara popular; que no caso as considerações teóricas estão em perfeita concordancia com a realidade. A consequencia fatal dessas afirmativas seria o reconhecimento de que, sem isso, não póde haver federação, porque, sem isso, o regime ficará desnaturado. 0 monografista conclue, entretanto, por dizer que a ausencia daquela igualdade entre as duas câmaras, ausencia que desnatura o regime, não deve por si só levar-nos a negar o caráter federal de um Estado. A conclusão está brigando abertamente com as premissas.

Trazem outros á guisa de argumento o exemplo das constituições que a Alemanha e a Austria adotaram depois da guerra, e que se rebelam contra as idéas triunfantes na teoria e na prática do federalismo.

$E^{\prime}$ nesses dois estatutos políticos que se baseia um notavel jurisconsulto patrio para afirmar que a representação dos Estados em uma câmara alta já hoje não constitue elemento substancial do sistema federativo. A resposta deu- 
a o sr. Odilon Braga na exaustiva exposição de motivos que apresentou á Comissão Constitucional: "Mais natural, disse êle, nos parece contestar o caráter federativo, com que essa organização se disfarça. Negar que a autonomia constitucional dos Estados membros e a participação desses na criação da vontade do Estado federal sejam o "signum specificum", que extrema o Estado federal do Estado unitario descentralizado, só porque alguns paizes se rotulam indevidamente com o nome de federação é, afinal, erigir em teoria o que não passa de empirismo, e preparar a confusão babélica das nomenclaturas"

Mas quem mais contribuiu para a difusão da heresia foi Mirkhine - Guetzevitch. Incompetente, como de público e humildemente me confesso, não serei eu quem ponha em dúvida a autoridade do jurista slavo; mas a sinceridade me obriga a dizer que o mestre novo não satisfaz os velhos estudantes como eu, acostumados ao convivio com os clássicos de direito.

Aquilo que faz a popularidade do livro dêle sobre as tendencias contemporaneas do direito constitucional é precisamente o seu maior defeito: a superficialidade do pensamento jurídico. Nada de orgânico ou de suculento ou de robusto. Uma simples vulgarização das inovações adotadas nas leis fundamentaes de paizes nascidos ou reestruturados em consequencia da guerra mundial; e, para justificar essas manifestações de cubismo jurídico, frutos aborticios da anarquia espiritual da época, uma fórmula tão vistosa quanto falsa: a racionalização do poder, isto é, a substituição da política pelo direito na organização do estado.

Fórmula falsa, manifestamente falsa em seu conteúdo, porque parte de um antagonismo, que não existe, entre a política e o direito público. Este, na expressão de Bluntschli, estuda o Estado em seu organismo, em sua estrutura, em suas condições permanentes e fundamentaes; aquela, o Estado em movimento ou em ação. De sorte que, longe de se contrariarem, ambas se conjugam e completam: a políti- 
ca tem de se mover dentro dos limites que lhe traça o direito, sob pena de se transformar no mais desenfreado dos egoismos, e o direito ha de obedecer aos ensinamentos da política, se não quizer distanciar-se das realidades e tornarse esteril e infecundo. Outra não é a opinião de Mouskheli, que tão a meude venho invocando. Nesta materia (diz êle) não é facil distinguir o direito da política. O texto formal não logra a sua significação plena, se não á luz do seu alcance prático; e é preciso amalgamar o direito com a política, para que a ciencia jurídica seja uma ciencia viva, e não uma construção teórica sem relação com a vida concreta.

Fórmula falsa, redondamente falsa em sua aplicação, porque a racionalização do sentido de que se trata só poderia ser produto de meditação acurada em ambiente propício; e não ha como qualificar dessa fórma as construções improvisadas pela inexperiencia e pela paixão de líderes esquerdistas, sob a pressão de massas destituidas de educação democrática, em paizes esgotados moral e materialmente pelos horrores da luta armada e pela humilhação da derrota; construções que por isso mesmo tiveram vida tormentosa e precaria, desmoralizando-se ao cabo de pouco tempo e aniquilando-se afinal sob o tacão da ditadura.

São decepcionantes as cinco ou seis paginas magras, em que Mirkhine Guetzevitch expõe sucintamente e justifica a seu modo o pseudo federalismo alemão, de saudosa memoria, e o pseudo federalismo austríaco, de saude tão periclitante. De fato, êle é o primeiro a confessar as tendencias rasgadamente unitaristas, que inspiraram essas duas organizações malogradas e que se manifestaram de maneira inequívoca e positiva com a adopção de unicameralismo. Assim é que, privados de qualquer intervenção na elaboração das leis, o Conselho do Imperio alemão e o Conselho Federal austríaco ficaram apenas com o direito ilusorio de vetar os projetos votados respetivamente pelo Reichsrath e pelo Conselho Nacional; o que importa no desaparecimento do sinal específico do Estado federal que, se- 
gundo vimos ha pouco é a participação estadual na formação da vontade soberana da União. $\mathrm{Na}$ ausencia dessa condição existencial do regime federativo, teremos diante de nós um estado unitario mais ou menos descentralizado e nada mais. Era o caso da Alemanha, ao tempo da constituição de Weimar. E' o caso da Austria.

A objeção não é aceitavel, obtempera Mirkine Guetzevitch. Porque? Porque são menos verdadeiras as premissas. Não. Porque a conclusão não decorre delas necessariamente? Não. Ouçamos a resposta: sendo o fedederalismo austriaco a ultima etapa da racionalização no federalismo, a Austria é certamente um Estado federal. Não ha exemplo mais acabado daquele conhecidíssimo sofisma que tem o nome de petição de principio. Compreende-se o embaraço do autor. E' que em verdade a suposta racionalização do federalismo consiste pura e simplesmente em falsifica-lo, desnatura-lo, suprimi-lo. Com a mesma seriedade poderiamos dizer que a substituição de um chefe de estado eletivo e temporario por um monarca absoluto viria racionalizar a república; ou, em outra ordem de idéas, que a castração racionaliza o sexo.

São estas as conclusões de tamanha e tão fastidiosa demonstração :

- o sistema bi-cameral se tem revelado sempre em toda parte mais vantajoso do que o sistema oposto;

— e é o único admissivel nos Estados federaes.

Firmados esses dois postulados, que julgo inabalaveis, resta-me confrontar com êles a solução que deu ao problema fundamental da organização do poder legislativo a constituição de 16 de julho.

Fal-o-ei amanhã, para não abusar por mais tempo da atenção que me vem sendo dispensada pelos colegas e que se justifica tão somente pelo interesse, pela gravidade, pela relevancia da questão em debate" 


\section{A GESTAÇÃO DO SENADO ATUAL}

Recordei em minha oração de ôntem que a revolução de 30 formara uma atmosfera espessa de prevenção e odiosidade contra o velho Senado, convertido por decreto sumaríssimo em bóde expiatorio dos pecados mortaes e veniaes do regime anterior.

O sr. Eloi de Souza - Mas os acusadores já se penitenciaram.

O sr. Alcantara Machado - Era assim de esperar que o ante-projeto de Itamarati, adotasse, como adotou, a unicameralidade. A' guisa de sucedaneo daquela casa de Congresso, vinha um Conselho Supremo, destinado a garantir o equilibrio federativo, mediante a representação igualitaria dos Estados e do Distrito Federal, e tambem a construir, de acôrdo com a fraseologia dos líderes do momento, o órgão técnico e político de supervisão e coordenação das atividades governamentaes, com funções consultivas e deliberativas. Diga-se de relance que não passava de extravagancia incrivel a pretensão de assegurar o equilibrio fedetivo, por meio de uma corporação, que além dos vinte e um representantes do Distrito Federal e dos Estados, teria ainda oito membros eleitos por varias entidades, e mais seis nomeados pelo presidente da República. E, sempre de passagem, assinale-se o hibridismo desse órgão de ordem técnica, mas constituido, em sua imensa maioria, de acôrdo com o critério politico.

Era de esperar tambem que se refletisse no seio da Assembléa Nacional Constituinte a propaganda desencadeada contra a câmara alta. Quasi todas as bancadas com efeito, traziam inscrita em seus programas a unificação do corpo legislativo. Duas apenas, se não me trae a memoria, consignavam entre os postulados que se propunham a defender, a instituição de uma câmara em que os Estados 
particulares tivessem o mesmo numero de representantes, a par de outra, formada de representantes em número proporcional á população. As delegações que assim pleiteavam a equivalencia, em um dos ramos do Poder Legistativo, de todas as unidades federativas, grandes ou pequenas no ponto de vista demográfico, eram precisamente as dos maiores Estados da União: a de Minas Geraes e a paulista da Chapa Unica. Por um fenômeno verdadeiramente paradoxal, as vozes que se faziam ouvir contra a dualidade partiam das bancadas dos Estados menores, que tinham interesse vital em sustentá-la.

Diante da desproporção numérica entre as duas correntes, o unicameralismo, já vitorioso no ante-projeto, parecia fadado a triunfo inevitavel no plenario. Para conjurar o perigo que estava correndo a sorte do federalismo brasileiro surgiu então a lembrança de uma fórmula conciliatoria. Fórmula radicalmente defeituosa como todas as transações em materia de principios, mas imposta pela necessidade de evitar mal maior. Perfilhou-a o substitutivo da Comissão Constitucional, onde se encontra um sistema equidistante do ante-projeto, que concentrava a função legislativa em uma só assembléa, e da emenda mineira, que restabelecia o Senado, tal qual se configurava na lei fundamental de $\mathbf{9 1 .}$ Haveria, partícipes do mesmo poder, a Câmara dos Representantes, com interferencia em toda a legislação federal, e uma Câmara dos Estádos, que só em certos e determinados casos seria chamada a cooperar com a outra na creação de lei. Como consequencia, o Conselho Supremo, transformado em Conselho Nacional, perderia o feitio de sucedâneo do Senado, passando á categoria de corporação meramente consultiva.

Na segunda discussão a fórmula conciliatoria do substitutivo conquistou, em princípio, a adesão das correntes mais volumosas da assembléa. Algumas, porém entenderam de prestigiar a Câmara dos Estados, dando-lhe algumas atribuições que o ante-projeto conferia ao Conselho Supremo e outras que o substitutivo reservava ao Con- 
selho Nacional. Como consequencia do enxerto dessas funções mais ou menos platônicas, a Camara dos Estados se enfeitava com as insignias de coordenadora dos poderes federaes; e dahi nasceu a idéa de transferi-la do titulo da Contituição referente ao Poder Legislativo para um titulo á parte. Foi o que se fez. Tudo para impedir a dispersão dos elementos mais ou menos moderados; o que aproveitaria á falange dos unitaristas impenitentes. Tudo pelo desejo teimoso de conciliação e transigencia, que inspirava as forças conservadoras da Constituinte.

Disse-o em paginas preciosas para o conhecimento do que sucedeu na Constituinte o ilustre sr. Odilon Braga: "Amparadas a conhecidos chefes militares, as correntes da esquerda não se conformavam com a restauração da segunda câmara. Era a volta ao passado, diziam. Inflamados, os seus capitães mal dissimulavam as ameaças em voga.

Foi nesse ambiente que tiveram logar as reuniões chamadas de coordenação, em que Minas, S. Paulo, o Rio Grande do Sul, a Baía, Pernambuco e Rio de Janeiro tudo fizeram em cerca de 30 dias de trabalho, para reduzir ao mínimo possivel as suas divergencias e facilitar entendimentos com os demais Estados, dest'arte assegurando a formação de maiorias, mais ou menos constantes, para o apoio da obra constitucíonal a surgir. No jogo das forças políticas, a Baía representava, por esse tempo, papel de avultada importancia, não só por ser baiano o ilustre lider da Assembléa, como principalmente pela posição de equilibrio em que surgia no balanço das votações. A Baía, impregnada de ideologia esquerdista, tomou a si a tarefa de tentar um novo esforço de conciliação do qual resultaram as emendas ns. 1948 e 1949. Desaparecida a dualidade formal do Poder Legislativo, embora em substancia subsistissem os seus efeitos, transformava-se o Senado em um orgão de coordenação dos demais poderes, com as funções mais ou menos idênticas a um quarto poder Assim se procedia, ademais, sob a impressão de uma circunstancia de inesperadas e importantissimas repercussões: a organização do bloco dos pe- 
quenos Estados, sob a direção do ilustre Ministro Juarez Tavora, que dispunha, por vezes, da aliança da representação profissional".

Eis aí sumariada a gestação tormentosa e dificil do atual Senado. Explica-se dessa forma, conhecidos os fatores estranhos que lhe perturbaram o desenvolvimento normal, a sentença implacavel que lavrou contra êle Pontes Miranda: "nas funções, complexo; nas materias de que trata e na conceituação, aberrante das regras da teoria dos órgãos do Estado; e na colocação, extravagante, senão surpreendente" o que forçou aquelle insigne jurisconsulto a procurar no vocabulario de teratologia o unico adjetivo capaz de classifica-lo.

\section{V}

\section{A CONCEITUAÇÃO JURIDICA DO SENADO BRASILEIRO}

Não ha, com ef eito, como classifica-lo ou conceitua-lo juridicamente.

Constituirá o Senado Federal, por si só, um dos poderes. do Estado, tendo assim razão os que nele divisam e proclamam o poder coordenador? Não. A pretensão esbarra desde logo, no texto cristalino do art. $3 .^{\circ}$, que só admite a existencia de tres poderes ou órgãos da soberania nacional: o legislativo, o executivo e o judiciario. $\mathrm{O}$ argumento desafia a contestação e desanima o sofisma, tão claro e terminante é o preceito constitucional. Note-se que, embora não houvesse no corpo da Constituição a enumeração taxativa dos poderes estataes, usurparia o nome de coordenadora uma Câmara que, dentre as suas doze atribuições, só tem duas, em que a análise vislumbra alguma coisa de coordenação: a do art. 91, n. II, que lhe dá o direito de suspender a execução dos dispositivos ilegaes dos regulamentos expedidos pelo executivo, e o do numero IV, que lhe confere igual faculdade, com referencia a qualquer lei, ato, deliberação ou regulamento, declarados inconstitucionaes pelo Judiciario. 
A verdade é que se trata de uma creação singular, única, ímpar, que de boa fé ninguem poderá enquadrar no conceito do poder coordenador, tal qual foi definido por Alberto Torres, que o imaginou. Basta lembrar que, de acôrdo com o projeto do saudoso pensador fluminense caberia a esse órgão da soberania apurar as eleições nacionaes ; resolver os conflitos entre as autoridades federaes ou entre as provinciaes e as municipaes; declarar, genérica e obrigatoriamente, a inconstitucionalidade das leis e dos atos da União, das provincias e dos municipios; reclamar as modificações das leeis provinciaes e municipaes que se tornassem necessarias á sua harmonisação com a política, a legislação e os interesses geraes e permanentes do paiz; e assim por diante. Além do Conselho Nacional, haveria, para auxilia-lo na execução do seu papel eminentíssimo um procurador da União em cada província, um delegado federal, não só em cada município, como em cada distrito de paz e até em cada quarteirão. Compare-se o que seria esse aparelho, anatômica e fisiologicamente, com o que é o Senado, e verse-á quando este se distancia daquele, por felicidade nossa.

Se não é um poder distinto, será o Senado parte de um dos enumerados no art. $3 .^{\circ}$ da lei fundamental?

Só poderá sel-o, evidentemente, do legislativo. E' o resultado a que chegou v. exa., sr. presidente, em luminosa conferencia, pronunciada perante o Instituto da Ordem dos Advogados da Baia, e a que tambem chega, com algum es forço, Pontes de Miranda, em um dos seus eruditos comentarios. E' a conclusão que parece autorizar a exigencia da nossa colaboração para a perfeição de certas leis, e, ainda, a incumbencia, que se confere á Secção Permanente desta casa, de zelar pelas prerogativas daquele poder, no intervalo das sessões legislativas.

Mas, em que pese a autoridades tamanhas, não faltam opiniões contrarias prestigiadas por homens do valor de Araujo Castro e Levi Carneiro, e apoiadas em textos constitucionaes bem expressivos e claros. A começar pela circunstancia eloquentissima, de se haver deslocado para um 
titulo diverso do que se inscreve "do poder legislativo" tudo quanto respeita á organização e á competencia do Senado. A continuar pela oposição constante que a constituição teima em suscitar entre as duas expressões, no empenho de esclarecer que se trata de entidades completamente distintas. Veja-se, por exemplo, o art. 91, n. 6, em que se confere ao Senado o direito de "organizar a sua Secretaria, propondo ao poder legislativo a creação ou supressão de cargos e dos vencimentos respectivos" A terminar, como elemento histórico, pelo testemunho de Odilon Braga, que foi o relator competentíssimo da materia no seio da comissão constitucional, e de quem são estas palavras textuaes: "Dizer-se, como faz o art. 22, que o Poder Legislativo é exercido pela Câmara com a colaboração do Senado é dar a supôr que tal poder se constitue pela Câmara e pelo Senado, quando na realidade êle somente se exerce pela assembléa dos representates do povo e das profissões, embora em alguns casos, tenha de atender ao voto do Senado. Está bem claro que o poder legislativo é exercido pela assembléa da qual ( o Senado) não passa de orgão auxiliar" Ao que acóde Pontes de Miranda: "nada justificaria que se reputasse órgão auxiliar" o Senado, quando êle colabora por vezes com a Câmara "no mesmo grau de igualdade"

Não me arrisco, sr. presidente, a pronunciar-me — quem sou eu? - por qualquer dos gigantes em conflito. Limitome a assinalar que, longe de ser clara e precisa como convem a uma lei desta natureza, em materia assim fundamental, a constituição de $\mathbf{1 6}$ de Julho se mostra sibilina e confusa, abrindo margem ás divergencias mais sérias entre as autoridades de maior conceito.

\section{VI}

\section{O SENADO BRASILEIRO E O FEDERALISMO}

A essas objeções de ordem jurídica, outras se juntam, igualmente ponderosas. 
Assim é que as restrições ás faculdades legislativas do Senado investem contra um dos principios básicos do regime federativo, isto, é contra a participação da câmara representativa dos Estados particulares na creação da vontade soberana da União.

Julgo ter demonstrado em meu discurso anterior, com a lição dos mestres e com o ensinamento dos factos, que essa participação deve ser completa, estendendo-se a toda a atividade legislativa. Os proprios autores, que se recusam a considerar a colaboração em debate como elemento vital da federação, confessam que se trata de uma de suas condições naturaes ou de uma de suas consequencias lógicas, o que basta para a minha argumentação. Não é só: as proprias constituições que estabeleceram o pseudo federalismo allemão e o pseudo federalismo austríaco, excluiram da elaboração legislativa a segunda câmara destinada á re presentação dos paizes, mas deram a esta ultima o direito de veto a todo e qualquer projeto de lei, sem restrição alguma, votado pela câmara popular. De sorte que, de certa forma, foram além da Constituição de 34 .

Nenhuma razão de ordem doutrinaria concorre em favor da solução brasileira. Expressões ou traduções da vontade nacional são todas as leis aplicaveis ao paiz inteiro. Porque se requer a intervenção dos Estados particulares, por seus representantes, na decretação dos tributos e tarifas, e havemos de dispensa-la na votação da receita ou da despesa orçamentarias?

O sr. Pires Rebello - Muito bem.

O sr. Alcantara Machado - Porque devem ser ouvidos nas questões de direito penitenciario, e se não admite a sua audiencia em materia de direito penal? Porque será precisa a interferencia do Senado na regulamentação das desapropriações, e não na regulametnação da propriedade? Poderiamos ir, assim, multiplicando indefinidamente as perguntas, que não encontram resposta satisfatoria. Tanto basta para evidenciar que a discriminação das materias não obedeceu a nenhum criterio jurídico. 
Terá seguido um criterio político? Tambem não. Quem o esclarece é Araujo Castro: “Ao passo que pela Constituição de 1891 o Senado colaborava na votação de todas as leis, atualmente a sua ação é bastante restrita, não lhe sendo licito intervir na votação de leis de grande interesse para a vida do paiz, como as de orçamento, fixação de forças armadas, creação e supressão de cargos publicos, fixação e alteração de vencimentos, operações de crédito, emissão de papel moeda, etc. Procurou-se dar ao Senado competencia naquilo que mais diretamente interessa aos Estados; mas não é possivel admitir que êles não tenham interesse nos assuntos acima referidos. Nem siquer lhe foi conferida a atribuição para legislar sobre telégrafos e estradas de ferro, serviços esses em que os Estados são diretamente interessados".

Se não existem fundamentos de ordem jurídica ou política para justificar essa limitação puramente arbitraria, sobejam os motivos de ordem prática para condená-la. Será frequentemente dificil encontrar uma linha de demarcação, nítida e precisa, entre certas materias, que são da competencia da Câmara, tão sómente, e outras em que o Senado tem de interferir com o seu voto. Repetidos e, o que é peor, insoluveis, serão os conflitos positivos ou negativos entre as duas entidades. Dúvidas têm surgido, nestes dois anos de prática constitucional, em casos que não as comportam. Não quero, nem devo citar exemplos: os factos aí estão, flagrantes e vivos, na conciencia de quantos me ouvem. Se tem sido assim em casos que nos parecem liquidos, imagine-se o que não será em casos que se prestam a controversia.

Tudo isso mostra ainda uma vez o perigo de abandonar os caminhos que a teoria e a prática do regime federativo apontam para tomar veredas incertas e rumos desconhecidos. Cada vez me convenço mais de verdade daquele velho conceito de Lamartine: "as experiencias em materia politica são catástrofes" 
O que ha de mais curioso na organização atual do Seuado é o contraste entre a imponencia de sua fachada e a penúria de sua realidade interior.

O sr. Pires Rebello - Muito bem.

O sr. Alcantara Machado - Quando a Constituinte de 1934 o inventou, não faltou quem nêle enxergasse um super-poder, um orgão hipertrófico, um aparelho capaz de invalidar o executivo, paralisando-lhe os movimentos, desviando-lhe a trajetória, e terminando por obsorvê-lo. Ou êle se anulará (anunciou o ilustre sr. Pedro Vergara, que foi um dos mais eficientes e brilhantes representantes da cultura gaucha na Assembléa Nacional), ou êle se anulará, desmoralizando-se submisso ao poder pessoal do presidente, ou será o verdadeiro poder executivo da República, anulando a presidencia e o ministerio"

Tudo porque o artigo 81 da Constituição definiu esta Câmara de modo enfático, em desacôrdo flagrante com as funções que lhe outorgou.

Aí se começa, com efeito, pela declaração de que ao Senado incumbe promover a coordenação dos poderes federaes entre si.

Nada mais impressionante para quem se contenta, como dizia Troplong, com a casca das palavras. Mas, se passarmos á análise das atribuições que podem ser qualificadas como funções de coordenação verificamos que elas se redusem, de facto, a quasi nada. São a meu ver as do artigo 91, II a IV. Com boa vontade chegaremos a acrescentar a do n. 3. ${ }^{\circ}$ III do mesmo dispositivo. E' tudo; e é tão pouco que não basta para justificar o vistoso e o espalhafatoso do rótulo.

A instituição de um órgão especial de coordenação dos poderes federaes entre si não seria, aliás, nem possivel, 
nem necessaria. Não seria possivel, porque importaria em lhe reconhecer uma preeminencia incompativel com os principios fundamentaes do direito público. Expressões iguaes, que são da soberania nacional, não ha possibilidade lógica de subordinar o executivo ou o legislativo ou o judiciario ás determinações de uma vontade estranha. Nem seria preciso fazê-lo, porque a cooperação se opera natural e necessariamente. A coordenação ou seja a colaboração reciproca decorre implicitamente do regime que adotamos. Chamoulhe Stuart Mill a moralidade constitucional do paiz. Dicey, por seu turno, acentua que a distribuição da atividade limitada, entre os corpos coordenados, mas independentes, uns em relação aos outros, é essencial á forma federativa de governo. Araujo Castro espelha o sentir comum, quando observa que a independencia dos poderes não significa, absolutamente, que êles não devam agir com mútua inteligencia e harmonia, isto é, coordenadamente, colaborando todos para o mesmo fim, que é o supremo interesse da nação. Pedro Calmon assinala que, se cada um dos poderes exercesse completamente, fóra do espirito de cooperação que realiza o governo, as suas faculdades, impossivel seria a movimentação da coisa pública.

Além dessa função teoricamente impossivel e praticamente desnecessaria, porque a coordenação é consequencia lógica da coexistencia de orgãos da soberania, que atuam dentro do limites prefixados na Constituição e obedecem á mesma finalidade, que é o bem estar nacional, o artigo 88 outorga ao Senado a de manter a continuidade administrativa. Como poderá exercê-la, se a administração, no sentido proprio, incumbe ao poder executivo de que o Senado não participa?

Tanto quanto me ajuda a inteligencia, a única das atri buições especificadas no artigo 90 e seguintes, que, neste particular, nos possibilitaria a atuação, está no artigo 91 n. V: "organizar com a colaboração dos Conselhos Técnicos, ou dos Conselhos geraes em que êles se agruparem, os planos nacionaes" 
Ora, essa faculdade, que se nos outorga parece mais platônica do que positiva. Primeiro, porque não a exerceremos em caráter privativo, e sim, conjuntamente com outros órgãos; e no caso de conflito entre a vontade destes e a nossa, não se sabe ao certo qual delas deverá prevalecer afinal. Segundo, porque de nada valerá formular os planos, uma vez que, em regra, não estará ao nosso alcance fornecer os recursos para executá-los: as leis orçamentarias escapam á competencia do Senado. Terceiro, porque, com exceção do plano nacional de educação, todos os outros poderão ser reformados á discrição do poder legislativo, no curso de cada quatriênio, e hão de sê-lo, provavelmente, no começo de cada um dêles, de acôrdo com a orientação dos novo responsaveis pela administração federal. Ou muito me iludo, ou, em materia de continuidade administrativa, a nossa interferencia lembra aquela faca, de que falava o meu saudoso mestre João Mendes Junior, que não tinha cabo, nem lamina.

\section{CONCLUSÃO}

E' tempo, de rematar as considerações que desde ôntem venho desenvolvendo em torno do problema da configuração do legislativo na Constituição de $\mathbf{1 6}$ de Julho.

Trata-se, a meu ver de uma creação condenada pela sabedoria politica, que exige a bipartição do legislativo em duas câmaras, para impedir o despotismo inevitavel das assembléas únicas, para facilitar a solução dos conflitos com o executivo, para compôr as forças de renovação e de conservação das sociedades humanas; - incompativel com o dualismo consubstancial ao regime federativo, que reclama a participação dos Estados, pelos ministerio de uma câmara especial que os represente, na formação da vontade federal, ou seja na definição das normas aplicaveis a todo o territorio da União; - inqualificavel no ponto de vista juridico; - inconveniente e manca em seus efeitos práticos. Não irei ao extremo de dizer que seja monstruosa, como 
têm insinuado ou afirmado alguns mestres de direito. Confessarei, apenas, humildemente, que traduz um erro, a que fomos levados, os constituintes de 1934, pela contingencia em que nos vimos, de transigir no terreno dos principios para dar ao paiz uma constituição que, embora defeituosa e imperfeita, repuzesse o Brasil dentro da lei. Sirva-nos de 'justificativa ou de excusa aquilo que, em direito penal, se chama o estado de necessidade.

Passou, mercê de Deus, aquela ansia de novidades forasteiras, aquele apetite furioso de mudar os quadros tradicionaes, tão conformes com os sentimentos do povo e os interesses permanentes da nacionalidade. Diga o Senado, digam os responsaveis pelos destinos da patria, se não é chegado o momento de corrigir as anomalias e os vicios da carta fundamental.

Pela voz de seus delegados legítimos e genuinos, pelo órgão dos deputados da Chapa Unica, São Paulo pleiteou sempre e unicamente que se atualizasse a Constituição de 91, isto é, que se lhe atenuasse o individualismo excessivo, dando um sentido humano ás normas juridicas: que se fizesse, pelo saneamento do processo eleitoral, a reforma dos nossos costumes políticos, e que se reforçasse a autoridade da União, sem sacrificio da autonomia dos Estados na direção dos seus negocios peculiares. Mas respeitando religiosamente, nos alicerces e nas vigas mestras o edificio erguido em 1891 pelo genio de Rui Barbosa, de Julio de Castilhos, de Prudente de Moraes, de tantos outros evangelistas da República.

O sr. Eloi de Souza - Apoiado.

O sr. Alcantara Machado - Eis porque como líder que me orgulho de ter sido da bancada paulista na Constituinte, me considero no dever moral de continuar nesta obra que ali iniciámos, em defesa dos ideaes democráticos e do regime federativo, e de reclamar que com êle se conforme a organização do poder legislativo da União. 